\title{
ПРАВОВОЕ РЕГУЛИРОВАНИЕ ПРЕКРАЩЕНИЯ ПОЛНОМОЧИЙ СУДЕЙ СУДОВ ОБЩЕЙ ЮРИСДИКЦИИ В 1917-1938 гг.
}

\begin{abstract}
Аннотация: В статье анализируется эволюция законодательства по одному из малоисследованньх вопросов в отечественной науке. Выделяются основные этапы в правовом регулировании прекращения полномочий судей, рассматриваются законодательные пробель; на основании архивных данных прослеживается практика реализации правовых норм. Делается вывод, что отсутствие в нормативных актах оснований для отзыва или привлечения к дисциплинарной ответственности, а также неурегулированноть процедуры отзыва стали причиной массового снятия судей со своих должностей и заложили основу для «чисток» судейского корпуса в 30-е годы ХХ века.
\end{abstract}

Ключевые слова: Судебная реформа, декрет, отзыв, дисииплинарная ответственность, народный суд, губернский суд, Верховный Суд, закон, реализация.

(1) равовое регулирование вопросов прекращения полномочий судьи, по справедливому замечанию М.И. Клеандрова, «а значит, категорический запрет неправомерных приостановления и прекращения полномочий», является одной из важнейших гарантий независимости судей ${ }^{1}$.

В дореволюционной России основания и процедуру прекращения полномочий судей детально регламентировали судебные уставы 1864 г., однако после прихода к власти большевиков они фактически утратили силу.

Первым нормативным актом советского правительства, в котором закреплялся порядок прекращения судейских полномочий, стал Декрет о суде № 2 от 07 марта 1918 г. $^{2}$ В принятом 22 ноября (5 декабря) 1917 г. Декрете о суде № $1^{3}$ этот вопрос, как и многие другие, оставался неурегулированным. Объясняя схематичный характер Декрета о суде № 1, один из его создателей, П. И. Стучка, утверждал, что «суть декрета заключалась в двух положениях: разогнать старый суд и отменить все старые законы. И только» 4 . На наш взгляд, более верна позиция А.В. Верещагиной, полагающей, что закрепление Декретом о суде № 1 только в общих чертах «контуров» юстиции свидетельствует «об отсутствии у большевиков представлений

\footnotetext{
${ }^{1}$ Клеандров М. И. Правовые основы статуса судьи. М., 2010. С. 179.

2 Декрет ВЦИК от 07.03.1918 г. № 2 «О суде» // СУ РСФСР. 1918. № 26. Ст. 347.

3 Декрет СНК РСФСР от 24.11.1917 г. «О суде» // СУ РСФСР. 1917. № 4. Ст. 50.

${ }^{4}$ Цит. по: Алакпаров К.А. Становление отечественного суда и формирование принципов судопроизводства в 1917 - 1936 гг. Дис. ... канд. юр. наук. М., 2005. С. 37.
}

о желательном судоустройстве и судопроизводстве» ${ }^{5}$. Действительно, объявив о ликвидации старых судов, новая власть не предложила им на смену ничего, кроме «местных судов».

Декрет о суде № 2 лишь частично восполнил пробельность в вопросе прекращения полномочий судей. Ч. 2 ст. 2 указывала, что избранные члены суда, «не исключая председателей, отзываются избравшими их Советами». При этом, декрет распространял право отзыва лишь на судей окружных народных судов, созданных этим же декретом. Ничего не говорилось о прекращении полномочий местных судов, организованных на основании Декрета о суде № 1, не регламентировалась процедура отзыва, не закреплялись основания для него.

Отметим, что хотя на тот момент мировая практика и знала институт отзыва должностных лиц ${ }^{6}$, для России он был явлением абсолютно новым. Так, судебные уставы 1864 г., действовавшие до 1917 г., закрепляли принцип несменяемости судей. Что касается представительных учреждений, то с момента их возникновения в России «депутат теоретически обладал свободным мандатом - он представлял не избирателей своего округа, а население всей империи» 7 .

Впервые институт отзыва в России вообе был закреплён декретом ВЦИК от 23 ноября 1917 г. «О праве отзыва

\footnotetext{
${ }^{5}$ Верещзагина А.В. Декрет № 1 о суде: история подготовки и его содержание // Журнал российского права. 2011. № 6. С. 103.

${ }^{6}$ См. подробнее: Руденко В.Н. Институты «отзыва» и «роспуска» в современном российском законодательстве: практика реализации и проблемы правового регулирования// Журнал российского права. 2002. № 4 .

${ }^{7}$ Петрова A.B. Конституционно-правовой институт отзыва в Российской Федерации: дис ... канд. юр. наук. М., 2006. С. 93.
} 
делегатов» ${ }^{8}$. В своём докладе на заседании ВЦИК 21 ноября 1917 г., настаивая на принятии декрета, В.И. Ленин отмечал: «Вопрос о перевыборах - это вопрос действительного осуществления демократического начала... во все исторические революционные времена, через все изменения конституций красной нитью проходит разрешение права отзыва»9.

Положение о народном суде, утверждённое декретом ВЦИК от 30 ноября 1918 г. ${ }^{10}$ (далее - Положение о народном суде 1918 г.), учредившее на всей территории РСФСР «единый народный суд», примечанием к ст. 13 распространило право отзыва и на народных судей. Инициатива проведения отзыва принадлежала Советам Рабочих и Крестьянских депутатов или Исполнительным комитетам Съездов Советов, их избравшим. Таким образом, законодательно получил закрепление принцип отзыва судей тем органом, которым они были избраны. Иных оснований прекращения полномочий судей предусмотрено не было. Отсутствие законодательно закрепленного срока полномочий народного судьи исключало даже такое основание, как истечение указанного срока.

В связи с этим, в народный комиссариат юстиции (далее - наркомат юстиции) стали поступать запросы, «надлежит ли считать, что народные судьи избираются бессрочно, или же их полномочия имеют определённый срок (и какой именно)» ${ }^{11}$ В ответ было дано разъяснение наркомата от 29 сентября 1920 г., что определенного срока полномочий для народных судей законом не установлено. Судьи избираются бессрочно и остаются в своих должностях до отзыва их избравшими учреждениями. Поэтому общие перевыборы народных судей являются недопустимыми, возможен лишь персональный отзыв того или иного судьи и избрание на его место другого лица ${ }^{12}$.

Отсутствие детальной регламентации процедуры отзыва привело к немотивированным отзывам судей на местах, фактической их зависимости от исполкомов. Так, ревизия судов Самарской губернии, проведенная в 1920 г., показала, что на отдельных территориях «народные суды разгоняются местными властями, судьи арестовываются без достаточных оснований» ${ }^{13}$.

\footnotetext{
8 Декрет ВЦИК от 24.11.1917 «О праве отзыва делегатов» // СУ РСФСР. 1917. № 3. Ст. 49.

9 Ленин В. И. Доклад о праве отзыва на заседании ВЦИК 21 ноября (4 декабря) 1917 г. // Полное собрание сочинений. Изд. 5-е. М., 1974. T. 35. C. 110.

10 Декрет ВЦИК от 30.11.1918 г. «О Народном Суде Российской Социалистической Федеративной Советской Республики (Положение)» // СУ РСФСР. 1918. № 85. Ст. 889.

${ }^{11}$ Государственный архив Курской области (далее - ГАКО). Ф. 451. Оп. 1. Д. 8. Л. 35.

12 Там же. Л. 72.

${ }^{13}$ Цит. по: Лезов И.Л. Советский суд в 1917-1940 гг. Дис. ... канд.
} юр. наук. М., 1998. С. 54.
Сложившаяся ситуация не могла не вызвать озабоченность законодателя. На заседании коллегии наркомата юстиции от 18 июня 1920 г. было решено «признать правильным постановку вопросов о пересмотре Положения о Народном суде, как то... вопрос отзыва судей» ${ }^{14}$.

Новое «Положение о Народном суде» было принято 21 октября 1920 г. ${ }^{15}$ Вопросы отзыва судей регулировала ст. 15, дополняющая и конкретизирующая нормы предшествующих декретов. В частности, указанная статья закрепляла, что народные судьи могут быть отозваны избравшими их Советами или уездными исполнительными комитетами, причем такой отзыв должен был быть подробно мотивирован и подлежал утверждению Губернского исполнительного комитета (далее - губисполком), по даче заключения Отделом юстиции. Временно, до утверждения отозвания губисполкомом, судьи могли быть отстраняемы от должности Советом народных судей.

Интересно, что в первоначальной редакции встречалась фраза «отзыв возможен лишь на основании данных, проверенных Губсовнарсудом или Отделом юстиции», но в окончательную редакцию она не вошла ${ }^{16}$.

Наркомат юстиции старался тщательно следить за соблюдением процедуры отзыва. Так, когда бывший судья 2 участка Городецкого уезда г. Гомеля Павлов подал в наркомат заявление о неправильном его отозвании городским уездным исполкомом, наркомат юстиции обратился в уездный исполком с требованием сообщить мотивировку, представленную для отозвания Павлова, а также прислать копию заключения Губюста ${ }^{17}$.

В 1922 г. в РСФСР была проведена судебная реформа, призванная решить назревшие проблемы в законодательстве и практике его реализации. Её проведение, по мнению А. С. Смыкалина, обуславливалось «провозглашением в стране новой экономической политики и наличием большого объём несистематизированного нормативного материала, а также существенных пробелов в законодательстве» ${ }^{18}$.

Базовым документом реформы 1922 г. в сфере судоустройства стало «Положение о судоустройстве РСФСР» 1922 г. ${ }^{19}$ Устанавливалась новая судебная система: народные суды - губернские суды - Верховный Суд

\footnotetext{
${ }^{14}$ Государственный архив Российской Федерации (далее - ГА РФ). Ф. А-353. Оп. 4. Д. 1. Л. 26.

15 Декрет ВЦИК от 21.10.1920 г. «Положение о Народном Суде Российской Социалистической Федеративной Советской Республики» // СУ РСФСР. 1920. № 83. Ст. 407.

${ }^{16}$ ГА РФ. Ф. А-353. ОП. 4. Д.1. Л. 27.

${ }^{17}$ ГА РФ. Ф. А-353. Оп. 4. Д. 60. Л. 46

${ }^{18}$ Смыкалин А. С. История судебной системы России. М., 2010. C. 144.

${ }^{19}$ Постановление ВЦИК от 11.11.1922 «О введении в действие Положения о судоустройстве Р.С.Ф.С.Р.» // СУ РСФСР. 1922. № 69. Ст. 902.
} 


\section{Право и политика 5 (161) 2013}

РСФСР. Законодательно закреплялись принципиально новые нормы, регулирующие статус судей (отметим, что законодатель отказался от их объединения в специальную раздел или главу, что свидетельствует о невнимании правительства к данному институту: большевики не нуждались в независимом суде, неподконтрольном центральной власти).

К основаниям прекращения полномочий судей «Положение о судоустройстве РСФСР» 1922 г. относило:

1) окончание срока полномочий. Данное основание в законе прямо не закреплялось; лишь ст.ст. 13 и 42 регламентировали сроки полномочий для народных судей и судей губернских судов соответственно;

2) отзыв. По-прежнему действовал принцип, что отзыв судьи осуществляет орган, его избравший. Поэтому Положение разграничивало порядок отзыва в зависимости от занимаемой должности. Народный судья отзывался на основании решения гбисполкома. Инициатором отзыва мог выступать как наркомат юстиции, так и сам губиспоком. В последнем случае губисполком был обязан сообщить наркомату юстиции об отзыве с обязательной мотивацией решения (ст. 13).

Губисполкому предоставлялось также право отзыва председателя, заместителя председателя и членов губернского суда. Односторонний отзыв указанных должностных лиц постановлением губисполкома не допускался, обязательно требовалась санкция наркомата юстиции (ст. 42).

Председателя, заместителей председателя и членов Верховного Суда РСФСР мог отозвать только Президиум ВЦИК (ст. 57).

Закрепляя в «Положении о судоустройстве РСФСР» 1922 г. отзыв как основание прекращение полномочий судьи, законодатель по-прежнему не регламентировал причины его применения. Подобная правовая неопределенность во-первых приводила к катастрофической текучести кадров в судах, снятии судей с должности с голословным указанием на «несоответствие должности», «невнушение доверия» и т.д. ${ }^{20}$ Во-вторых, она стала основой для будущих «чисток», начавшихся уже в середине 1920-х гг. и приобретших массовый характер в 1930-е гг. Так, уже в мае 1925 г. наркомат юстиции санкционировал снятие с должности судей и прокурорских работников «за потерю классовой бдительности» ${ }^{21}$.

3) смещение с должности по суду или в порядке дисциплинарного производства. Отметим, что в ряде случаев имело место нарушение норм «Положения о судоустройстве РСФСР» 1922 г., когда губернский суд (далее - губсуд), усматривая в действиях судей престу-

\footnotetext{
${ }^{20}$ ГАКО. Ф. Р-166. ОП. 1. Д. 27. Л. 63

${ }^{21}$ ГА РФ. Ф. А-353. Оп. 16. Д. 15. Л. 26-26 об.
}

пления, предусмотренные Уголовным Кодексом 1922 г. ${ }^{22}$ (преимущественно речь шла о должностных преступлениях, регулируемых главой второй УК), ставил вопрос перед губисполкомом об отзыве судьи, а не привлечении его к суду ${ }^{23}$.

Данная практика не применялась, когда судья обвинялся в получении взятки: указанное преступление считалось одним из серьёзных, дискредитирующих облик советского судьи. Показательной является речь А.Я. Вышинского, произнесённая им на процессе по делу ленинградских судебных работников: группы из одиннадцати судей и следователей, которая «по предварительному между собой сговору, в нарушение своего служебного долга, явно подрывая авторитет судебной власти, в видах личного обогащения вступила на путь систематического взяточничества» ${ }^{24}$. Выступая на этом процессе в качестве государственного обвинителя, А.Я. Вышинский отметил: «Это дело имеет исключительное значение, так как здесь мы судим судей - тех, кто призваны быть первыми помощниками в деле государственного строительства, ибо без суда нет государства, ибо без суда нет государственного строительства, ибо только в том случае государство может рассчитывать на свою жизненность, если крепки его устои, если крепки его органы, если судьба этих органов находится в руках надёжных людей, если призванные защищать интересы государства - действительно достойные его защитники, какими являются и должны быть раньше всего наши судьи» ${ }^{25}$.

Взяточничество как должностное преступление предусматривалось несколькими статьями Уголовного Кодекса РСФСР 1922 г. Осознавая особую общественную опасность получения взятки судьями, законодатель ввёл в УК наряду со ст. 114 («получение лицом, стоящим на государственной, союзной или общественной службе, лично или через посредников в каком бы то ни было виде взятки за выполнение или невыполнение в интересах дающего какого-либо действия, входящего в круг служебных обязанностей этого лица»), ст. 111, объявляющую преступлением «постановление судьями из корыстных или иных личных видов неправосудного приговора». Впрочем, по словам П. Соломона, «выдвижение конкретных обвинений судьям было редким делом, поскольку обвинения в коррупции оказывались труднодоказуемыми» ${ }^{26}$. Исследователь приводит пример, когда в 1926 г. одно дело завершилось оправданием об-

\footnotetext{
22 Постановление ВЦИК от 01.06.1922 «О введении в действие Уголовного Кодекса Р.С.Ф.С.Р.» // СУ РСФСР. 1922. № 15. Ст. 153.

${ }^{23}$ См., напр. ГАКО. Ф. Р-166. Оп. 1. Д. 6. Л. 42.

${ }^{24}$ Вышиинский А. Я. Судебные речи. М., 1948. С. 5

${ }^{25}$ Там же. С. 10

${ }^{26}$ Соломон П. Советская юстиция при Сталине. М., 2008. С. 54.
} 
виняемого, доказавшего, что автор доноса испытывает у нему личную неприязнь. Однако уже в 1928-1929 гг. пять судебных дел закончилось осуждением обвиняемых ${ }^{27}$.

Порядок смещения судей с должности в порядке дисциплинарного производства регулировался ст.ст. 69-84 «Положения о судоустройстве» 1922 г. Интересно отметить, что нормы Положения в части прекращения судебных полномочий во многом повторяли аналогичные нормы судебных уставов 1864 г., хотя еще в 1917 г. был провозглашён отказ от законов царского правительства.

Правом на возбуждение дисциплинарного производства в отношении судей общей юрисдикции обладали:

1) Прокурор Республики - в отношении всех без исключения лиц, работающих в судебных учреждениях РСФСР;

2) Председатель Верховного Суда и состоящий при Верховном Суде помощник Прокурора Республики - в отношении всех судебных работников, работающих в учреждениях, находящихся в ведении Верховного Суда, т.е. председателей коллегий и членов коллегий Верховного Суда, председателей и заместителей председателей губернских судов и равных им судов, губернских прокуроров и их помощников и всех состоящих при губернском суде должностных лиц;

3) председатели губсудов и губернские прокуроры - в отношении всех лиц, работающих в подведомственных губсуду учреждениях.

Поводами для возбуждения дисциплинарного производства, согласно ст. 73 «Положения о судоустройстве» 1922 г. являлись:

a) проступки, поведение или действия судебных работников, хотя бы и не наказуемые уголовными законами, но несовместимые с достоинством и назначением судебных деятелей. Перечень указанных проступков был законодательно не определён. На практике к ним относили, в частности, халатное или невнимательное отношение к служебным обязанностям, самовольный выезд из участка или самовольное оставление службы, волокита в производстве дел, отказ принять кассационную жалобу, поданную в положенный срок и т.д. Неудивительно, что большинство дел, возбуждённых по таким основаниям, прекращалось за отсутствием состава дисциплинарного производства ${ }^{28}$;

б) отмена Верховным Судом ряда приговоров и решений, вынесенных судебными работниками, по несоответствию таковых общему духу законов РСФСР и интересам трудящихся масс.

Дисциплинарное производство могло быть начато не позднее одного года со времени совершения поступка.

\footnotetext{
27 Там же.

${ }^{28}$ ГАКО. Ф. Р-166. Оп. 1. Д. 7. Л. 88; ГАКО. Ф. Р-166. Оп. 1. Д. 51. Л. 3 и др.
}

Хотя зачастую непереизбрание обвиняемого на должность судьи автоматически влекло отказ от возбуждения в отношении него дисциплинарного производства ${ }^{29}$. Не имело значения, совершен ли судьёй проступок при исполнении им своих служебных обязанностей, или вне их.

Предварительный разбор дела происходил в дисциплинарной коллегии. Она собирала необходимые справки, требовала объяснения от обвиняемого и могла персонально поручить произвести расследование члену коллегии, или члену губернского суда, или народному судье, по принадлежности.

Явка обвиняемого для дачи личных объяснений на заседание в обязательном порядке не требовалась. Исключение составляли случаи, когда «в случае необходимости» дисциплинарная коллегия вызывала обвиняемого ко времени разбора дела.

При рассмотрении дела дисциплинарная коллегия не была связана никакими формальностями, процедура производства всецело зависела от усмотрения коллегии. Однако законодатель выдвигал условие, что »если коллегия выслушает заключение прокурора, то после него предоставляется слово обвиняемому».

В случае, если дисциплинарная коллегия усматривала в разбираемых деяниях признаки уголовно наказуемого деяния, она была обязана, приостановив производство, передать дело по подсудности следственным властям.

В порядке дисциплинарного производства налагались следующие взыскания:

а) замечание;

б) выговор;

в) перемещение и смещение на низшую должность;

г) отстранение от службы с запрещением работы в судебных должностях на срок.

Постановления дисциплинарных коллегий губернских судов могли быть обжалованы в семидневный срок в Верховный Суд. Постановления дисциплинарной коллегии Верховного Суда никакому обжалованию не подлежали.

Образование СССР в декабре 1922 г. потребовало принятия общесоюзного акта о судебной системе, тем более, что п. «П» Конституции СССР 1924 г. ${ }^{30}$ относил к ведению Союза Советских Социалистических Республик в лице его верховных органов «установление основ судоустройства и судопроизводства, а также гражданского и уголовного законодательства Союза». Сама Конституция практически не регулировала вопросов судоустройства и статуса судей; лишь в главе VII в самом общем виде устанавливались основы организации и деятельности Верховного Суда СССР. Вместе с тем, Конституция СССР 1924 г.,

\footnotetext{
${ }^{29}$ См., напр.: ГАКО. Ф. Р-166. Оп. 1. Д. 7. Л. 153.

${ }^{30}$ Основной Закон (Конституция) Союза Советских Социалистических Республик // СУ РСФСР. 1923. № 81. Ст. 782.
} 


\section{Право и политика $5(161) \cdot 2013$}

вводя в систему органов государственной власти Союза Верховный Суд СССР, не регламентировала порядок отзыва его членов. Этот пробел был восполнен постановлением ЦИК СССР от 14 июля 1924 г. «Наказ Верховному Суду Союза Советских Социалистических Республик» ${ }^{31}$ В ст. 2 Наказа законодатель указывал, что «Председатель, его заместитель и все члены Верховного Суда Союза ССР... назначаются Президиумом Центрального Исполнительного Комитета Союза ССР и только им же могут быть отозваны или отстранены от должности».

29 октября 1924 г. были приняты «Основы судоустройства Союза ССР и союзных республик» (далее - Основы 1924 г.) ${ }^{32}$ - акт, носящий рамочный характер, определяющий основные начала судебной системы как Союза, так и входящих в его состав республик. Закрепляя в П. «б» ст. 3 основной принцип формирования судов общей юрисдикции, Основы 1924 г. передавали на уровень республик вопросы формирования судейского корпуса.

После принятия Основ 1924 г. началось приведение законодательства республик в соответствие с общесоюзным (отметим, что дальнейшем, выработался определенный алгоритм в судебном законодательстве: сначала принималась Конституция СССР, на основании неё-закон о судоустройстве СССР, а уже затем нормативно-правовые акты о судоустройстве республик и иных территориальных образований). Так, 23 октября 1925 г. принято «Положение о судоустройстве УССР» ${ }^{33}, 31$ октября 1925 г. - «Положения о судоустройстве БССР» ${ }^{34}, 2$ ноября 1925 г. Декрет ВЦИК, СНК РСФСР «Об утверждении Положения о судоустройстве Северо-Кавказского края» ${ }^{35}, 23$ ноября 1925 г. - Декрет ВЦИК, СНК РСФСР »Об утверждении Положения о судоустройстве Сибирского края» ${ }^{36}$ и т.д. Только 19 ноября 1926 г. ВЦИК утвердил «Положение о судоустройстве РСФСР» ${ }^{37}$.

«Положение о судоустройстве РСФСР» 1926 г. подтвердило основания прекращения полномочий судей, регламентированных «Положением о судоустройстве РСФСР» 1922 г., внеся лишь незначительную корректировку. Так, в связи с предоставлением городским советом

${ }^{31}$ Постановление ЦИК СССР от 14.07.1924 «Наказ Верховному Суду Союза Советских Социалистических Республик» // С3 СССР. 1924. № 2. Ст. 25.

32 Основы судоустройства Союза ССР и союзных республик (утв. Постановлением ЦИК СССР от 29.10.1924) // СЗ СССР. 1924. № 23. Ст. 203.

${ }_{33}^{33}$ Собр. Узаконений и распоряжений Рабоче-Крест. Правительства Украины. 1925. № 92.

${ }^{34}$ СУ БССР 1925 г. № 29. Ст. 275.

${ }^{35}$ СУ РСФСР. 1925. № 77. Ст. 595.

${ }^{36}$ СУ РСФСР. 1925. № 82. Ст. 619.

${ }^{37}$ Постановление ВЦИК от 19.11.1926 г. «Об утверждении Положения о Судоустройстве Р.С.Ф.С.Р.» // СУ РСФСР. 1926. № 85. Ст. 624. право избрания народных судей, они так же наделялись правом отзыва (ст.16). Из-за введения новой административно-территориальной единицы - края - учреждались краевые суды. Основания прекращения полномочий устанавливались те же, что и для прочих судов; право отзыва принадлежало краевому исполнительному комитету при наличии санкции наркомата юстиции (ст. 112).

В дальнейшем законодательство, регулирующее основания прекращения полномочий судей, практически не менялось до второй половины 1930-х гг., когда в 1938 г., на основании Конституции СССР 1936 г., был принят закон «О судоустройстве СССР, союзных и автономных республик» ${ }^{38}$, кардинальным образом изменивший процедуру формирования судейского корпуса.

Рассматривая основания прекращений полномочий судей не следует забывать и законодательно не закреплённый, но на практике часто встречающийся добровольный уход с должности судьи. В анализируемый период престиж судейской профессии был чрезвычайно низок. Причиной этого выступали как тяжелое материальное положение судей $^{39}$, так и их зависимость от органов исполнительной власти, чему в немалой степени способствовало сосредоточение в руках последней полномочий по выборам и отзывам судей. Неоднократно с мест в Верховный Суд РСФСР поступали сообщения о фактах незаконного вмешательства советских и общественных организаций в оперативную работу судов. 20 декабря 1935 г. Верховный Суд РСФСР был вынужден приказом № 409 обязать членов Верховного Суда РСФСР, членов краевых (областных) и окружных судов выявлять на местах случаи подобного вмешательства и принимать необходимые меры. «Ни один такой факт не должен оставаться нерасследованным, - отмечалось в приказе, - не доведённым до конца в соответствующих руководящих органах» ${ }^{40}$. Однако, в рамках исследуемого периода проблема так и осталась нерешённой.

Итак, анализируя отечественное законодательство о прекращении полномочий судей, можно выделить два периода в его развитии, рубежом между которыми стал 1922 г. - год проведения судебной реформы. Правотворчество в 1917-1922 гг. в части прекращения полномочий судей носило экспериментальный характер. Отрицая апробированное десятилетиями дореволюционное законодательство в сфере судоустройства и

\footnotetext{
38 Закон СССР от 16.08.1938 г. «О судоустройстве СССР, союзных и автономных республик» // Ведомости ВС СССР. 1938. № 11.

${ }^{39}$ См., напр.: ГА РФ. Ф. А-353. Оп. 16. Д. 1. Л. 31; ГАКО. Ф. Р-166. Оп. 1. Д. 13. Л. 51; ГАКО. Ф. 451. Оп. 1. Д. 40. Л. 25об-26; Кодинцев А.Я. Государственная политика в системе органов юстиции СССР в 1933-1956 гг. Дис. ... докт. юр. наук. Екатеринбург, 2010.

${ }^{40}$ ГА РФ. Ф. А-353. Оп. 16. Д. 15. Л.59-59 об.
} 
судопроизводства, большевики не предложили собственной единой концепции по данным вопросам. И хотя в ходе разработки судебной реформы 1922 г. был сформирован перечень оснований прекращения полномочий судьи, фактически он представлял собой основания досрочного прекращения (лишения) полномочий. Отсутствие в нормативных актах оснований для отзыва или привлечения к дисциплинарной ответственности, а также неурегулированноть процедуры отзыва стали причиной массового снятия судей со своих должностей и заложили основу для «чисток» судейского корпуса в 30-е годы XX века.

\section{Библиография:}

1. Алакпаров К.А. Становление отечественного суда и формирование принципов судопроизводства в 1917 1936 гг. Дис. ... канд. юр. наук. М., 2005. 161 с.

2. Верещагина А.В. Декрет № 1 о суде: история подготовки и его содержание // Журнал российского права. 2011. № 6. С. 101-109.

3. Вышинский А. Я. Судебные речи. М.: Юридическое издательство министерства юстиции СССР, 1948. $539 \mathrm{c}$.

4. Декрет ВЦИК от 24.11.1917 г. «О праве отзыва делегатов» // СУ РСФСР. 1917. № 3. Ст. 49.

5. Декрет ВЦИК от 30.11.1918 г. «О Народном Суде Российской Социалистической Федеративной Советской Республики (Положение)» // СУ РСФСР. 1918. № 85. Ст. 889.

6. Декрет ВЦИК от 07.03.1918 г. № 2 «О суде» // СУ РСФСР. 1918. № 26. Ст. 347.

7. Декрет ВЦИК от 21.10.1920 г. «Положение о Народном Суде Российской Социалистической Федеративной Советской Республики» // СУ РСФСР. 1920. № 83. Ст. 407.

8. Декрет СНК РСФСР от 24.11.1917 г. «О суде» // СУ РСФСР. 1917. № 4. СТ. 50.

9. Закон СССР от 16.08.1938 г. «О судоустройстве СССР, союзных и автономных республик» // Ведомости ВС СССР. 1938. № 11 .

10. Клеандров М. И. Правовые основы статуса судьи. М.: Российская академия правосудия, 2010. 256 с.

11. Кодинцев А.Я. Государственная политика в системе органов юстиции СССР в 1933-1956 гг. Дис. ... докт. юр. наук. Екатеринбург, 2010. 576 с.

12. Лезов И.Л. Советский суд в 1917-1940 гг. Дис. ... канд. юр. наук. М., 1998. 161 с.

13. Ленин В. И. Доклад о праве отзыва на заседании ВЦИК 21 ноября (4 декабря) 1917 г. // Полное собрание сочинений. Изд. 5-е. Т. 35. М.: Изд-во политической литературы, 1974. С. 109-111.
14. Основной Закон (Конституция) Союза Советских Социалистических Республик // СУ РСФСР. 1923. № 81. Ст. 782 .

15. Основы судоустройства Союза ССР и союзных республик (утв. Постановлением ЦИК СССР от 29.10.1924 г.) // С3 СССР. 1924. № 23. Ст. 203.

16. Петрова А.В. Конституционно-правовой институт отзыва в Российской Федерации. Дис ... канд. юр. наук. М., 2006. 211 с.

17. Постановление ВЦИК от 01.06.1922«О введении в действие Уголовного Кодекса Р.С.Ф.С.Р.» // СУ РСФСР. 1922. № 15. Ст. 153.

18. Постановление ВЦИК от 11.11.1922 «О введении в действие Положения о судоустройстве Р.С.Ф.С.Р.» // СУ РСФСР. 1922. № 69. Ст. 902.

19. Постановление ВЦИК от 19.11.1926 г. «Об утверждении Положения о Судоустройстве Р.С.Ф.С.Р.» // СУ РСФСР. 1926. № 85. Ст. 624.

20. Постановление ЦИК СССР от 14.07.1924 г. «Наказ Верховному Суду Союза Советских Социалистических Республик» // СЗ СССР. 1924. № 2. Ст. 25.

21. Руденко В.Н. Институты «отзыва» и «роспуска» в современном российском законодательстве: практика реализации и проблемы правового регулирования// Журнал российского права. 2002. № 4. С. 44-53.

22. Смыкалин А. С. История судебной системы России. М.: ЮНИТИ-ДАНА, 2010. 231 с.

23. Соломон П. Советская юстиция при Сталине. М.: Российская политическая энциклопедия (РОССПЭН); Фонд Первого Президента России Б. Н. Ельцина, 2008. 464 c.

\section{Bibliography (transliterated):}

1. Alakparov K.A. Stanovlenie otechestvennogo suda i formirovanie principov sudoproizvodstva v 1917 - 1936 gg. Dis. ... kand. jur. nauk. M., 2005. $161 \mathrm{~s}$.

2. Verewagina A.V. Dekret № 1 o sude: istorija podgotovki i ego soderzhanie // Zhurnal rossijskogo prava. 2011. № 6. S. 101-109.

3. Vyshinskij A. Ja. Sudebnye rechi. M.: Juridicheskoe izdatel'stvo ministerstva justicii SSSR, 1948. $539 \mathrm{~s}$.

4. Kleandrov M. I. Pravovye osnovy statusa sud'i. M.: Rossijskaja akademija pravosudija, 2010. $256 \mathrm{~s}$.

5. Kodincev A.Ja. Gosudarstvennaja politika v sisteme organov justicii SSSR v 1933-1956 gg. Dis. ... dokt. jur. nauk. Ekaterinburg, 2010. 576 s.

6. Lezov I.L. Sovetskij sud v 1917-1940 gg. Dis. ... kand. jur. nauk. M., 1998. $161 \mathrm{s.}$

7. Lenin V. I. Doklad o prave otzyva na zasedanii VCIK 21 nojabrja (4 dekabrja) 1917 g. // Polnoe sobranie sochinenij. 


\section{Право и политика 5 (161) • 2013}

Izd. 5-e. T. 35. M.: Izd-vo politicheskoj literatury, 1974. S. 109-111.

8. Petrova A.V. Konstitucionno-pravovoj institut otzyva v Rossijskoj Federacii. Dis ... kand. jur. nauk. M., 2006. $211 \mathrm{~s}$.

9. Rudenko V.N. Instituty «otzyva» $\mathrm{i}$ «rospuska» v sovremennom rossijskom zakonodatel'stve: praktika realizacii i problemy pravovogo regulirovanija// Zhurnal rossijskogo prava. 2002. № 4. S. 44-53.

10. Smykalin A. S. Istorija sudebnoj sistemy Rossii. M.: JuNITI-DANA, 2010. $231 \mathrm{~s}$.

11. Solomon P. Sovetskaja justicija pri Staline. M.: Rossijskaja politicheskaja jenciklopedija (ROSSPJeN); Fond Pervogo Prezidenta Rossii B. N. El'cina, 2008. 464 s. 